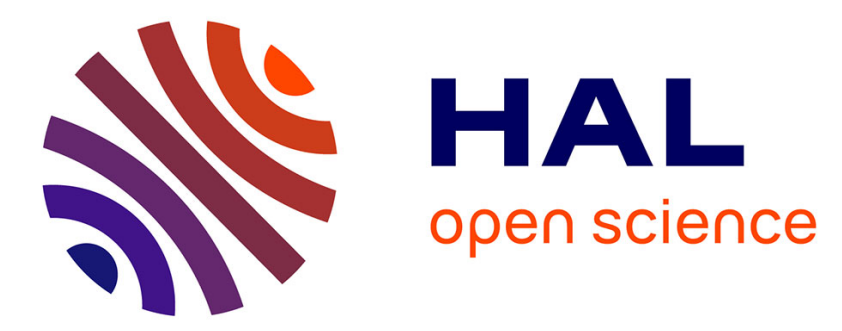

\title{
Novel and innovative interface as potential active layer in Chem-FET sensor devices for the specific sensing of Cs
}

\author{
Volkan Kilinc, Catherine Henry-De-Villeneuve, Tin Phan Nguy, Yutaka \\ Wakayama, Anne Charrier, Jean-Manuel Raimundo
}

\section{To cite this version:}

Volkan Kilinc, Catherine Henry-De-Villeneuve, Tin Phan Nguy, Yutaka Wakayama, Anne Charrier, et al.. Novel and innovative interface as potential active layer in Chem-FET sensor devices for the specific sensing of Cs. ACS Applied Materials \& Interfaces, 2019, 11 (50), pp.47635-47641. 10.1021/acsami.9b18188 . hal-02380343v2

\section{HAL Id: hal-02380343 \\ https://hal.science/hal-02380343v2}

Submitted on 3 Feb 2020

HAL is a multi-disciplinary open access archive for the deposit and dissemination of scientific research documents, whether they are published or not. The documents may come from teaching and research institutions in France or abroad, or from public or private research centers.
L'archive ouverte pluridisciplinaire HAL, est destinée au dépôt et à la diffusion de documents scientifiques de niveau recherche, publiés ou non, émanant des établissements d'enseignement et de recherche français ou étrangers, des laboratoires publics ou privés. 


\title{
Novel and innovative interface as potential active layer in Chem-FET sensor devices for the specific sensing of $\mathrm{Cs}^{+}$.
}

\author{
Volkan Kilinc, ${ }^{1,3}$ Catherine Henry-de-Villeneuve, ${ }^{2}$ Tin Phan Nguy, ${ }^{1,3}$ Yutaka Wakayama, ${ }^{3}$ Anne M. \\ Charrier $^{1^{*}}$ and Jean-Manuel Raimundo ${ }^{1 *}$ \\ ${ }^{1}$ Aix Marseille Univ, CNRS, CINAM, Marseille, France \\ ${ }^{2}$ Laboratoire de Physique de la Matière Condensée, Ecole Polytechnique, CNRS, IP Paris, 91128 Palaiseau, France. \\ ${ }^{3}$ International Center for Materials Nanoarchitectonics (WPI-MANA), National Institute for Materials Science (NIMS), 1-1 \\ Namiki, Tsukuba 305-0044, Japan
}

\begin{abstract}
An innovative novel interface has been designed and developed, in order to be used as a potential active layer in Chem-FET sensor devices for the specific sensing of $\mathrm{Cs}^{+}$. In this study, the synthesis of a specific $\mathrm{Cs}^{+}$probe based calix[4]arene benzocrown ether, its photophysical properties as well as its grafting onto a single lipid monolayer (SLM) recently used as efficient ultrathin organic dielectric in Chem-FETs are reported simultaneously. On the basis of both optical and NMR titration experiments, the probe has shown high selectivity and specificity for $\mathrm{Cs}^{+}$compared to interfering cations, even if an admixture is used. Additionally, ATR-FTIR spectroscopy was successfully used to characterize and prove the efficient grafting of the probe onto a SLM and the formation of the innovative novel sensing layer.
\end{abstract}

Keywords: Lipid monolayers, ultra thin dielectric, sensors, cesium detection, calixarene.

\section{INTRODUCTION}

Ultrafast ions trace quantification methods have attracted tremendous interest in the last decades with the aim to be applicable for the detection of hazardous cations and anions. In this context, we have focused our investigation on the $\mathrm{Cs}^{+}$detection motivated both by the recent accidents in nuclear power plants, the frequent discharges from the nuclear reactors and its uses in nuclear weapons testing. Additionally, cesium is used in food and drug sterilization processes; in medicine therapies ${ }^{1}$ and in many industrial applications such as optical glasses, photoelectric cells ${ }^{2}$ or ion propulsion systems. Radioactive cesium represents one of the most toxic elements that can be found in the flora and fauna, ${ }^{3,4}$ because it is easily displaced and incorporates in nature due to its high solubility in water, causing detrimental effects to the environment and human health. ${ }^{5,6}$

Hence, it is crucial to develop reliable and accurate methods for its detection and/or dosage in order to safeguard workers who are exposed daily to $\mathrm{Cs}^{+}$ensuring harmless uses and also safer working conditions. A rapid survey revealed that the most common method for detection is based on the conventional ICP-MS technique. ${ }^{7-10}$ Although accurate and sensitive, this technique is not suitable to achieve on-site and real-time measurements requiring expensive and sophisticated instrumentation as well as expert manpower. To overcome some of these drawbacks, chemists have devised optical methods based either on colorimetric or fluorometric assays by designing specific artificial hosts. Among them, 1,3-alternate calix[4]arenes-based scaffolds topped with a crown ether have gained a lot of attention due to their well-defined structures exhibiting a cavity that fits perfectly with the cesium ionic 
radius. ${ }^{11-13}$ Additionally it is easy to tag them with fluorophores such as naphthalene or anthracene, ${ }^{14}$ indanone ${ }^{15}$ or coumarin ${ }^{16,17}$ providing additional benefits in the modulation of optical properties.

However, practical uses need to integrate them into devices that allow in situ real-time monitoring. To this end, we believe that the use of field-effect transistors constitutes a promising and reliable technology, which is worth and valuable for such purpose allowing miniaturization and wearable sensor systems. Moreover, we have recently demonstrated that engineered single lipids monolayers (SLM) can be used as ultrathin dielectric leading to sensing properties with limits of detection down to the femtomole in Chem-FET sensors. ${ }^{18,-21}$

Figure 1. Schematic representation of an engineered SLM

Thus, in the line of our previous work, we will present herein the synthesis of a novel 1,3-alternate calix[4]arene host exhibiting high selectivity toward the foreseen $\mathrm{Cs}^{+}$analyte as shown by UV-Vis and NMR titration analysis and its successful anchoring atop of a SLM generating an innovative sensing interface. The grafting process was monitored by an in situ FTIR analysis using a homemade chamber that allows us to follow and characterize the direct functionalization of the SLM.

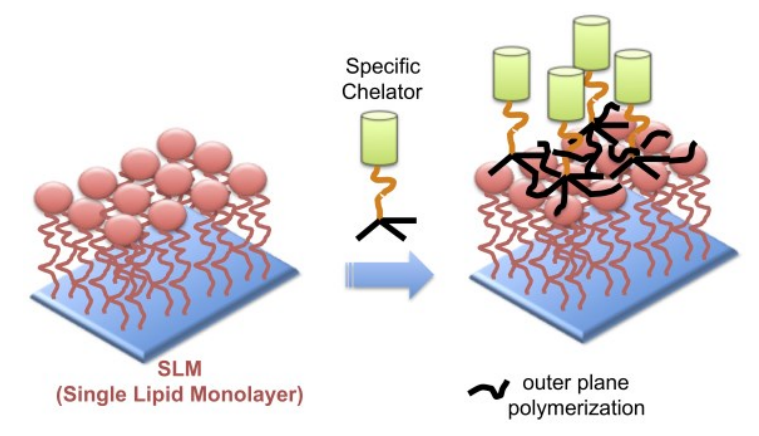

Figure 1: Schematic representation of an engineered SLM

\section{EXPERIMENTAL SECTION}

Reagents and Analysis. 2-(2-chloroethoxy)ethanol), Catechol and p-toluenesulfonyl chloride (TsCl) were purchased from TCI. Calix[4]arene and allyl bromide were purchased from Alfa Aesar. Karstedt's catalyst, $\mathrm{Li}^{+}$, $\mathrm{Na}^{+}, \mathrm{K}^{+}, \mathrm{Rb}^{+}, \mathrm{Cs}^{+}$, and $\mathrm{Mg}^{2+}$ as chlorine salts, dimethylformamide (DMF), anhydrous acetonitrile $\left(\mathrm{CH}_{3} \mathrm{CN}\right)$, methanol (MeOH), dichloromethane (DCM), tetrahydrofuran (THF), anhydrous toluene, anhydrous 1,4-dioxane, $\mathrm{K}_{2} \mathrm{CO}_{3}, \mathrm{NaOH}$ and $\mathrm{Cs}_{2} \mathrm{CO}_{3}$ were purchased from Sigma Aldrich. Column chromatography was performed using silica $60 \mathrm{M}(0.04-0.063 \mathrm{~mm})$ purchased from Macherey-Nagel.

Physicochemical Analysis. ${ }^{1} \mathrm{H},{ }^{13} \mathrm{C}$ and ${ }^{29} \mathrm{Si}$ NMR spectra were recorded on a JEOL ECS spectrometer at $400 \mathrm{MHZ}$ $\left({ }^{1} \mathrm{H}\right), 100 \mathrm{MHz}\left({ }^{13} \mathrm{C}\right)$ or $79 \mathrm{MHz}\left({ }^{29} \mathrm{Si}\right)$ at room temperature. NMR chemical shift are given in ppm $(\delta)$ relative to $\mathrm{Me}_{4} \mathrm{Si}$ with solvent resonances used as internal standards $\left(\mathrm{CDCl}_{3}: 7.26 \mathrm{ppm}\right.$ for ${ }^{1} \mathrm{H}$ and $77.2 \mathrm{ppm}$ for $\left.{ }^{13} \mathrm{C}\right)$. MS (ESI) analyses were performed on a SYNAPT G2 HDMS (Waters) spectrometer at the "Spectropole" of Aix-Marseille University. ${ }^{22}$ This instrument was equipped with an electrospray ionization source (ESI) and a TOF mass analyzer. The sample was ionized in electrospray positive mode with a tension of $2.8 \mathrm{kV}$, the orifice tension was $50 \mathrm{~V}$ and the $\mathrm{N}_{2}$ rate of flow was $100 \mathrm{~L} / \mathrm{h}$. XR diffraction was made on a Rigaku Oxford Diffraction SuperNova diffractometer and measured at 203, 250, and $150 \mathrm{~K}$, respectively, under $\mathrm{Cu}$ radiation $(\lambda=1.54184 \AA)$. Data collection, reduction, and multiscan ABSPACK corrections were performed with CrysAlisPro (Rigaku Oxford Diffraction). Using Olex $2,{ }^{23}$ the structures were solved with the ShelXT structure solution program using Intrinsic Phasing and refined with ShelXL using least-squares minimization. ${ }^{24}$ FTIR analysis was performed on an EQUINOX 55 spectrophotometer (Brucker, Germany) equipped with a liquid nitrogen-cooled Mercury-Cadmium Telluride photovoltaic detector. The ATR samples (FZ-purified Si(111) wafer, thickness 500-500 $\mu \mathrm{m}$ ) were shaped as prisms 
with two opposite sides beveled at $\sim 45^{\circ}$. Their length ( $\sim 15 \mathrm{~mm}$, for $c a \sim 30$ internal reflections) was chosen to obtain wide-range FTIR spectra $\left(1000-4000 \mathrm{~cm}^{-1}\right)$. Measurements were carried out in a $\mathrm{N}_{2}$-purged chamber in order to minimize $\mathrm{H}_{2} \mathrm{O}$ vapor and $\mathrm{CO}_{2}$ absorption. Spectra were averaged over 150 scans $\left(4 \mathrm{~cm}^{-1}\right.$ resolution).

Physicochemical Measurements in Solution. UV-Vis absorption spectra were obtained on a Jasco V-670 spectrophotometer. The electronic absorption maxima $\left(\lambda_{\max }\right)$ are directly extracted from absorption spectra of chelator 3 based solution. Under the optimum conditions the stoichiometry between the chelator 3 and the different analytes were investigated by the molar ratio method ${ }^{25,26}$ both in UV-Vis and ${ }^{1} \mathrm{H}$ NMR techniques.

Synthesis of 1,3-alternate 25,27-bis-(1-allyloxy)-1,3-[1,2-bis[2-(2-oxyethoxy)ethoxy]phenylene]calix[4]arene, 3. To a solution, under Argon atmosphere, of 1,3-diallyloxy calix[4]arene 1 ( $0.090 \mathrm{~g}, 0,180 \mathrm{mmol}, 1.0$ equiv) in 30 $\mathrm{mL}$ of anhydrous $\mathrm{CH}_{3} \mathrm{CN}$ was added, in one portion, $0.234 \mathrm{~g}(0.730 \mathrm{mmol}, 4.0$ equiv) of cesium carbonate. The reaction mixture was stirred under reflux for $2 \mathrm{~h}$ prior adding dropwise a solution of $0.120 \mathrm{~g}(0,198 \mathrm{mmol}, 1.1$ equiv) of 2 in $9 \mathrm{~mL}$ of anhydrous $\mathrm{CH}_{3} \mathrm{CN}$. The reaction mixture was refluxed for 2 days and then the reaction mixture was cooled down to room temperature. Solvent was removed under reduced pressure. The residue was taken up in 100 $\mathrm{mL}$ of $\mathrm{CH}_{2} \mathrm{Cl}_{2}$ and the organic phase was washed successively with $2 \times 60 \mathrm{~mL}$ of a $2 \mathrm{M}$ aqueous $\mathrm{HCl}$ solution, then twice with $50 \mathrm{~mL}$ of brine and twice with $50 \mathrm{~mL}$ of water. The organic phase was dried over $\mathrm{Na}_{2} \mathrm{SO}_{4}$, filtered and the solvent was removed under vacuo. The residue was purified by column chromatography over $\mathrm{SiO}_{2}$ (eluent: petroleum ether: EtOAc 8:2) yielding the titled compound in $61 \%$ as a colourless solid. $\mathrm{Mp}=142^{\circ} \mathrm{C}$ (uncorrected). ${ }^{1} \mathrm{H} \mathrm{NMR}\left(400 \mathrm{MHz}, \mathrm{CDCl}_{3}\right): \delta=7.00\left(\mathrm{~d}, 4 \mathrm{H},{ }^{3} \mathrm{~J}=7.5 \mathrm{~Hz}\right), 6.91\left(\mathrm{dd}, 8 \mathrm{H},{ }^{3} \mathrm{~J}=12.1,4.8 \mathrm{~Hz}\right), 6.60\left(\mathrm{td}, 4 \mathrm{H},{ }^{3} \mathrm{~J}=7.5,4.5\right.$ $\mathrm{Hz}), 5.65\left(\mathrm{ddt}, 2 \mathrm{H},{ }^{3} \mathrm{~J}=17.2,10.6,4.6 \mathrm{~Hz}\right), 4.97\left(\mathrm{dd}, 2 \mathrm{H},{ }^{3} \mathrm{~J}=10.7,1.7 \mathrm{~Hz}\right), 4.84\left(\mathrm{dd}, 2 \mathrm{H},{ }^{3} \mathrm{~J}=17.3,1.8 \mathrm{~Hz}\right), 4.09$ (t, $\left.4 \mathrm{H},{ }^{3} \mathrm{~J}=5.1 \mathrm{~Hz}\right), 4.03\left(\mathrm{dd}, 4 \mathrm{H},{ }^{3} \mathrm{~J}=4.1,2.0 \mathrm{~Hz}\right), 3.60(\mathrm{~m}, 20 \mathrm{H}) .{ }^{13} \mathrm{C} \mathrm{NMR}\left(100 \mathrm{MHz}, \mathrm{CDCl}_{3}\right): \delta=138.23 ; 138.02$; $131.16 ; 116.46 ; 115.64 ; 113.10 ; 112.21 ; 104.39 ; 104.29 ; 103.97 ; 97.95 ; 97.33 ; 52.93 ; 52.61 ; 52.34 ; 51.62$ ppm. MS $(\mathrm{ESI}+) \mathrm{m} / \mathrm{z}$ : 772.3849 found for $\left[\mathrm{M}+\mathrm{NH}_{4}\right]^{+}$; calculated for $\left[\mathrm{M}+\mathrm{NH}_{4}\right]^{+}$; 772.3844. Elemental analysis for $\mathrm{C}_{48} \mathrm{H}_{50} \mathrm{O}_{8}+\mathrm{CH}_{3} \mathrm{CN}(\%)$ : calculated $\mathrm{C}, 75.45 ; \mathrm{H}, 6.71 ; \mathrm{O}, 16.08$. Found $\mathrm{C}, 75.39 ; \mathrm{H}, 6.67 ; \mathrm{O}, 16,18$.

Colourless crystals of 3 were obtained by slow diffusion of a $\mathrm{CH}_{2} \mathrm{Cl}_{2}$ solution into $\mathrm{MeOH}$ solvent, with the monoclinic space group P21 with $a=11.3911$ (2) $\AA, b=10.4981$ (2) $\AA, c=17.4878$ (3) $\AA, \alpha=90^{\circ}, \beta=106.375$ $(2)^{\circ}, \gamma=90^{\circ}$ at $293 \mathrm{~K}$, with $\mathrm{Z}=2$ and $\mathrm{V}=2006.45$ (7) $\AA^{3}$. The refinement of 7060 reflections and 505 parameters yielded $\mathrm{R} 1=0.0428$ for all data (6283 reflections with $\mathrm{I}>2 \sigma(\mathrm{I})$ ) (See the Supporting Information). Atomic coordinates, bond lengths, angles and thermal parameters for $\mathbf{3}$ have been deposited at the Cambridge Crystallographic Data Centre (CCDC number: 1935509, DOI: 10.5517/ccdc.csd.cc22z1sx). Copies of the data can be obtained free of charge on application to CCDC, 12 Union road, Cambridge CB21EZ, UK. Email: deposit@ccdc.cam.ac.uk.

Synthesis of 1,3-alternate 25-[(3-triethoxy)-silyl-1-propyloxy]-27-(1-allyloxy)-1,3-[1,2-bis-[2-(2-oxyethoxy)ethoxy]phenylene]calix[4]arene, 4. To a solution, under Argon atmosphere, of 3 (0.050 g, $0.066 \mathrm{mmol}, 1.0$ equiv) in $2 \mathrm{~mL}$ of anhydrous was added $0.027 \mathrm{~mL}(0.145 \mathrm{mmol}, 2.2$ equiv) of triethoxysilane and the reaction mixture was stirred at room temperature for $20 \mathrm{~min}$. The reaction vessel was placed in a glove box then $0.020 \mathrm{~mL}$ of the Karstedt's catalyst was added dropwise. The reaction was warmed up to $50^{\circ} \mathrm{C}$ and was stirred for $12 \mathrm{~h}$. The reaction mixture was cooled down to room temperature and filtered through Celite pad. Excess of triethoxysilane and solvent were removed under reduced pressure. The product was used without further purification. ${ }^{1} \mathrm{H} \mathrm{NMR}(400 \mathrm{MHz}$, 
$\left.\mathrm{CDCl}_{3}\right): \delta=6.81\left(\mathrm{~m}, 16 \mathrm{H}, \mathrm{H}\right.$ aromatics), $5.69\left(\mathrm{~m}, 1 \mathrm{H}, \mathrm{H}\right.$ vinyl), $3.89\left(\mathrm{~m}, 36 \mathrm{H}, \mathrm{CH}_{2}\right), 1.25(\mathrm{~m}, 9 \mathrm{H}$, methyl), 0.94 $\left(\mathrm{m}, 2 \mathrm{H}, \mathrm{CH}_{2}\right) \mathrm{NMR}^{29} \mathrm{Si}\left(\mathrm{CDCl}_{3}, 79 \mathrm{MHz}\right): \delta-100(\mathrm{~s}, 1 \mathrm{Si})$.
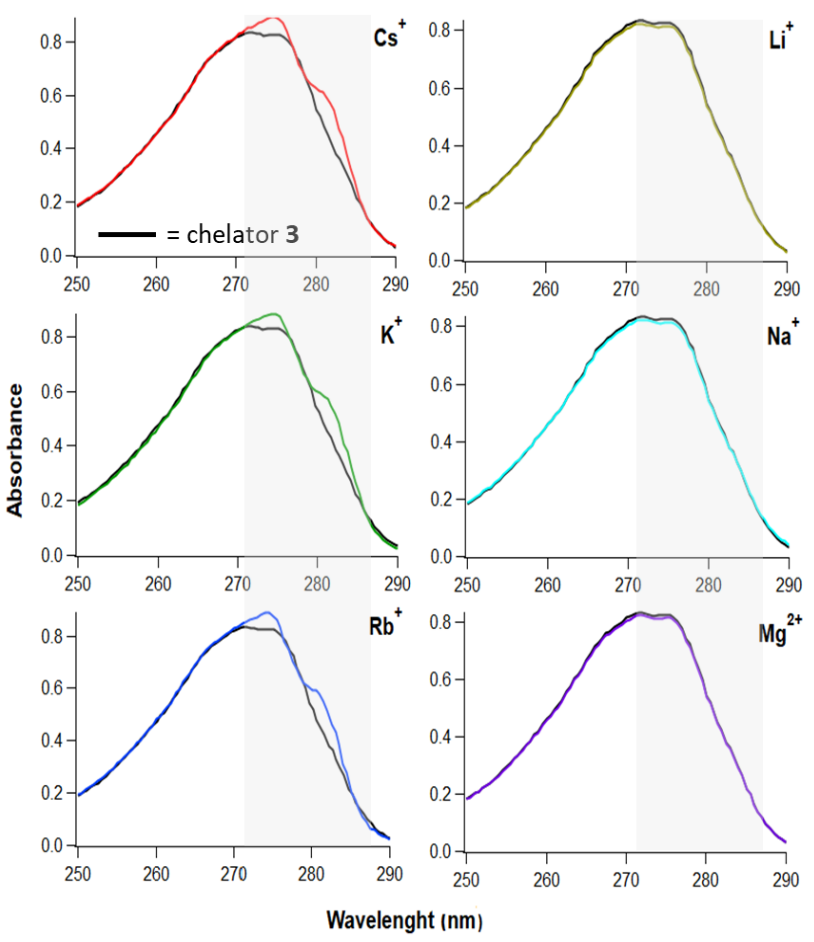

Figure 2: Optical properties of the receptor 3 (-) after addition of 1 equiv of $\mathrm{Li}^{+}(-), \mathrm{Na}^{+}(-), \mathrm{K}^{+}(-), \mathrm{Rb}^{+}(-), \mathrm{Cs}^{+}(-)$and $\mathrm{Mg}^{2+}(-)$ cations.

\section{RESULTS AND DISCUSSION}

The synthesis of the target chelator $\mathbf{3}$ is outlined in Scheme 1. Compound $\mathbf{3}$ was readily obtained from the cross coupling of the ditosylate 2 and the calix[4]arene $\mathbf{1}^{27,28}$ in $\mathrm{CH}_{3} \mathrm{CN}$ at $80^{\circ} \mathrm{C}$ in presence of $\mathrm{Cs}_{2} \mathrm{CO}_{3}$ in $61 \%$ yield. ${ }^{29}$ The ditosylate 2 was prepared according to reported literature procedures ${ }^{30,31}$ from commercially available catechol, which first was alkylated with 2-(2 chloroethoxy)-ethanol in the presence of $\mathrm{K}_{2} \mathrm{CO}_{3}$ in DMF to form a diol intermediate in $47 \%$ yield (see SI, S1). The latter was subsequently treated with $p$-toluenesulfonyl chloride in pyridine affording the ditosylate $\mathbf{2}$ in $62 \%$ yield (see SI figures S2). ${ }^{32,33}$

Scheme 1: Synthesis of the Chelator 3

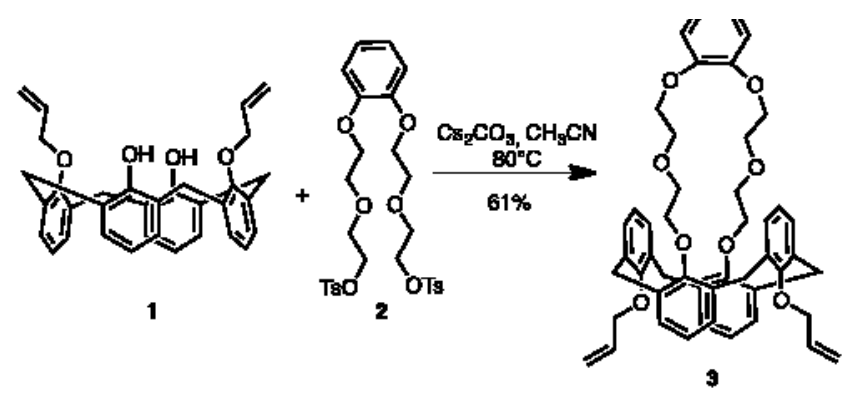

The optical properties, absorption and fluorescence emission of the chelator $\mathbf{3}$ have been investigated in a solvent mixture $\mathrm{MeOH}$ : DCM (v/v, 1:1). Ultimately, the receptor exhibited poor fluorescence properties and thereafter no further studies have been pursued by fluorescence spectroscopy. UV-visible absorption spectrum of the receptor 3 presents several absorption bands in the region 240-300 $\mathrm{nm}$ ascribed to the absorption of the benzene rings of both 
the calix[4]arene scaffold and the benzocrown ether. The cation binding properties of the chelator 3 were screened by UV-visible spectroscopy with several putative competitive monovalent cations $\left(\mathrm{Li}^{+}, \mathrm{Na}^{+}, \mathrm{K}^{+}, \mathrm{Rb}^{+}, \mathrm{Cs}^{+}\right)$and also with a divalent cation $\left(\mathrm{Mg}^{2+}\right)$ (Figure 2).

Job plots were performed using a solvent mixture of MeOH:DCM (SI figure S7) and clearly indicate, for the studied cations, the formation of a $[1+1]$ complex $\mathbf{3 . X ^ { + }}$, which is in agreement with the results reported on similar scaffolds. ${ }^{11-13}$ No further optical changes were observed after the addition of an excess of the cations. Moreover, it is important to notice that even in competitive polar solvent such as $\mathrm{MeOH}$ we observed for the cationic guest of interest, $\mathrm{Cs}^{+}$, some interactions with $\mathbf{3}$ allowing its detection. Furthermore, the minor optical changes upon the addition of the cationic guests constitute a proof that the host-guest interaction occurs predominantly in the crown ether part. This behaviour was further confirmed by ${ }^{1} \mathrm{H}$ NMR titration experiments (vide infra) and is consistent with the crystallographic observations obtained from X-ray structure of 3 (Figure 3 and SI figure S3). Further examination of the cavity size from the X-ray structure revealed that the measured distances $\mathrm{Cs}^{+}-\mathrm{O}(3.31 \AA)$ and $\mathrm{Cs}^{+}-\mathrm{Ar}_{\text {calix }}(3.44 \AA)$ are in accordance with similar reported systems indicating that the cavity of $\mathbf{3}$ is more suitable for the $\mathrm{Cs}^{+}$compared to the others. ${ }^{34}$

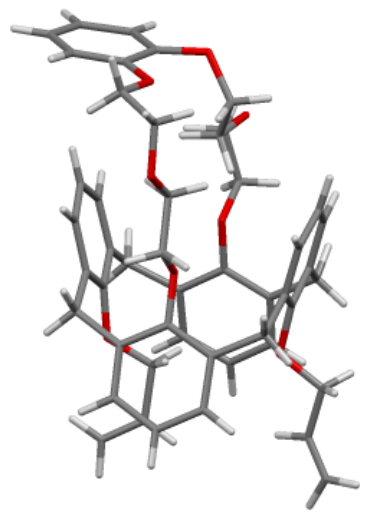

Figure 3: Crystal structure of 3 (C, gray, $H$, white, $O$, red).

The greater optical changes were observed for $\mathrm{Cs}^{+}, \mathrm{K}^{+}$and $\mathrm{Rb}^{+}$while for the others cations $\left(\mathrm{Na}^{+}, \mathrm{Li}^{+}\right.$and $\left.\mathrm{Mg}^{2+}\right)$ much smaller variations are observed, the spectra remaining almost unchanged. Upon addition of $\mathrm{Cs}^{+}, \mathrm{K}^{+}{\mathrm{or} \mathrm{Rb}^{+}}^{+}$ an enhancement of the absorption bands centered at $275 \mathrm{~nm}$ and $281 \mathrm{~nm}$ was observed, highlighting the formation 


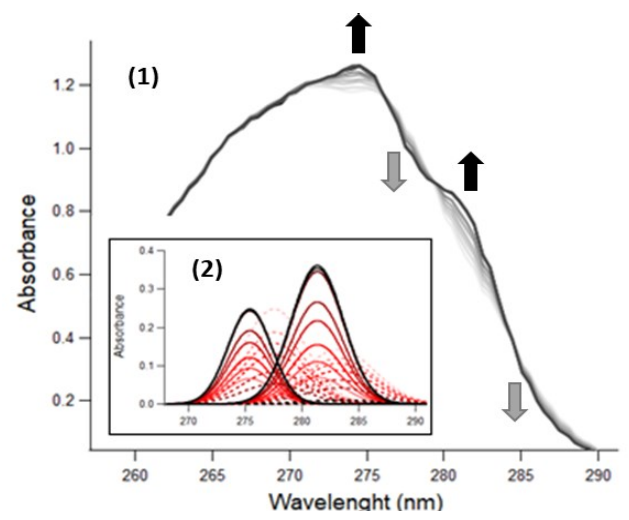

Figure 4: (1) Absorbance properties of the receptor 3 (-) upon the addition from 0 to 1 equiv of $\mathrm{Cs}^{+}$(light to dark). (2) (-) Inset: evolution of the absorbance at $\lambda$ of interest after a mathematical fitting. Full line corresponds to the black arrows whereas dashed line corresponds to the gray arrows of (1).

of the $3 . \mathbf{X}^{+}$complexes. It was anticipated that the presence of the benzene ring in the crown ether part could impart a reduction of the flexibility of the cavity preventing the complexation of smaller cations such as $\mathrm{Na}^{+}, \mathrm{Li}^{+}$and $\mathrm{Mg}^{2+}$. Although it is easy to differentiate between the ions interacting with the crown ether from those that cannot, due to the emergence of new peaks on the absorption spectra, it appears less obvious for $\mathrm{Cs}^{+}, \mathrm{K}^{+}$and $\mathrm{Rb}^{+}$because they displayed similar behaviours. Thus, in order to have a more pronounced difference between these three cations, giving a positive signal, it is necessary to apply a fitting mathematical function taking into account the spectral modifications (Figure 4, inset and SI figures S4-S6). For instance, upon the gradual addition of the $\mathrm{Cs}^{+}$cation the variations of the absorption properties of $\mathbf{3}$ are associated with hyperchromic (at $275 \mathrm{~nm}$ and $281 \mathrm{~nm}$ ) and

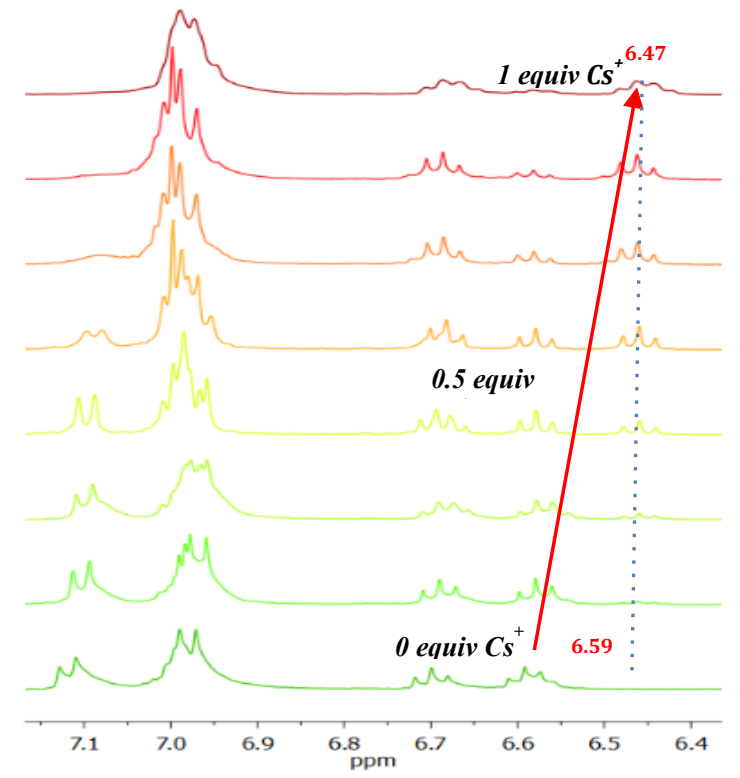

Figure 6: ${ }^{1} \mathrm{H}$ aromatic and aliphatic regions of 3 after saturation with $\mathrm{Cs}^{+}$and addition of 0 to 1 equiv of $\mathrm{Cs}^{+}$as chlorine salts in $\mathrm{CDCl}_{3}$ : $\mathrm{MeOD}(1: 1)$ with traces of $\mathrm{D}_{2} \mathrm{O}$.

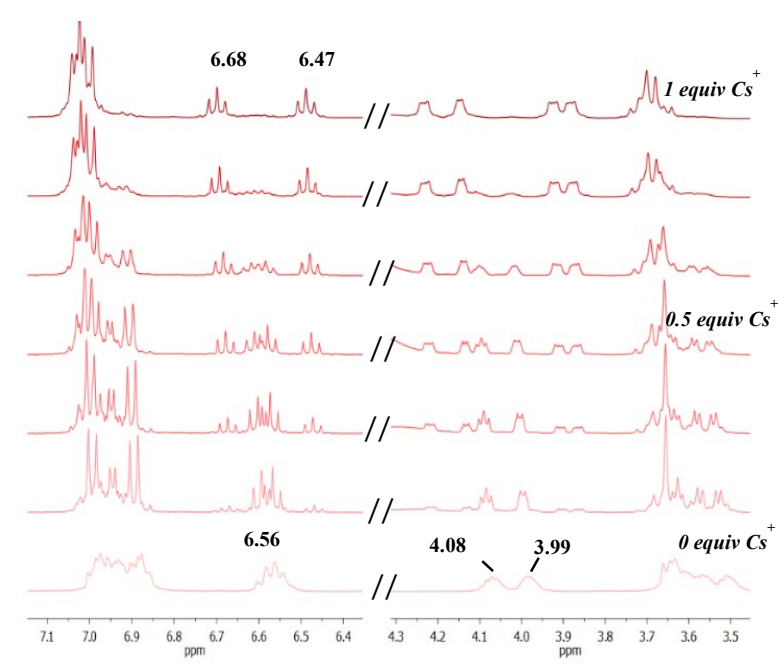

Figure $5:^{1} \mathrm{H}$ aromatic and aliphatic regions of 3 upon addition of 0 to 1 equiv of $\mathrm{Cs}^{+}$as chlorine salts in $\mathrm{CDCl}_{3}: \mathrm{MeOD}(1: 1)$ with traces of $\mathrm{D}_{2} \mathrm{O}$.

hypsochromic effects respectively (slightly blue-shifted from 277 to $275 \mathrm{~nm}$ and from 283 to $281 \mathrm{~nm}$ ). These optical changes and the appearance of isobestic points attest undoubtedly of the ability of $\mathbf{3}$ to bind these cations. On the basis of these results an approximate Hofmeister series can be settled, which follows approximately the radius of each cation: $\mathrm{Cs}^{+}>\mathrm{Rb}^{+}>\mathrm{K}^{+}>\mathrm{Na}^{+}>\mathrm{Li}^{+} \approx \mathrm{Mg}^{2+} \cdot{ }^{35,36}$ Hence, association constants can be determined using the BenesiHildebrand method ${ }^{37,38}$, showing that 3 presents the higher selectivity toward $\mathrm{Cs}^{+}$with a $\mathrm{K}_{\mathrm{a}}=6.02410^{3} \mathrm{M}^{-1}$ which 
is three or two-fold magnitude higher than the ones of $\mathrm{K}^{+}\left(2.82510^{3} \mathrm{M}^{-1}\right)$ and $\mathrm{Rb}^{+}\left(2.28810^{3} \mathrm{M}^{-1}\right)$, respectively (Table 1 and SI figure S8).

Table 1. Association constants $\left(K_{a}\right)$ determined in MeOH: DCM (1:1) at $293 \mathrm{~K}$ for the host-guest complexes 3. $\mathbf{X}^{+*}$

\begin{tabular}{llll}
\hline & & $\mathrm{K}_{\mathrm{a}} \cdot 10^{3} \mathrm{M}^{-1}$ & Stoichiometry \\
$\mathrm{Cs}^{+}$ & 6.024 & $1: 1$ & \\
$\mathrm{~K}^{+}$ & 2.825 & $1: 1$ & \\
$\mathrm{Rb}^{+}$ & 2.288 & $1: 1$ & \\
\hline
\end{tabular}

*Not determined for $\mathrm{Na}^{+}, \mathrm{Li}^{+}, \mathrm{Mg}^{2+}$, as no complexation occurs.

In order to get further information on the chelating ability of $3,{ }^{1} \mathrm{H}$ NMR titration experiments were conducted in a mixture of deuterated $\mathrm{CDCl}_{3}$ : MeOD (1:1) solutions in presence of traces of $\mathrm{D}_{2} \mathrm{O}$. By varying gradually the number of equivalents of each cation, it is clearly evidenced that the complexes $\mathbf{3} . \mathbf{X}^{+}$were formed. Indeed, both aromatic and aliphatic regions dramatically change as the number of equivalent of the added cation increases (Figure 5 and SI figure S10).

Most of the protons in these two regions are affected, shifting progressively downfield or upfield, and are preeminent after the addition of 1 equiv of $\mathrm{X}^{+}$. If an excess of cation $\mathrm{X}^{+}$is added no further chemical shift is noticed in these two regions. Remarkably, in the ${ }^{1} \mathrm{H}$ aromatic region of the free host 3 the multiplet centered at $6.56 \mathrm{ppm}$ splits into two separated triplet signals (one at downfield and the second one at upfield) after addition of 1 equiv of $\mathrm{Cs}^{+}$. Moreover, in the ${ }^{1} \mathrm{H}$ aliphatic region, the two multiplets centered respectively at 4.08 and 3.99 ppm are more strongly affected upon complexation as four new signals are observed both at downfield and upfield compared to the two original multiplets. These findings indicate that the binding of $\mathrm{Cs}^{+}$, as well as for the others cations takes place mostly, in the crown ether part as reported on similar systems. The excellent selectivity toward cesium was found and ascribed to the combined electrostatic and cation- $\pi$ interactions arising respectively from cesium and oxygens of the crown ether or the aromatic rings of the scaffold. ${ }^{11-13}$ In addition, the observed chemical shifts associated to the addition of the cations are greater when the $\mathrm{Cs}^{+}$is added compared to $\mathrm{K}^{+}$and $\mathrm{Rb}^{+}$pinpointing that the host molecule 3 interacts more strongly with $\mathrm{Cs}^{+}$than the others.

As previously demonstrated, $\mathrm{K}^{+}$and $\mathrm{Rb}^{+}$are putative interfering analytes for $\mathrm{Cs}^{+}$, even though they display lower affinity constants. In order to have more insights on that, guest-displacement experiments were performed both by UV-visible and ${ }^{1} \mathrm{H}$ NMR (Figure 6 and SI Figure S10).

As exemplified, starting from complex $\mathbf{3} . \mathrm{K}^{+}$the incremental addition of $\mathrm{Cs}^{+}$amounts leads to a dramatically change of the ${ }^{1} \mathrm{H}$ NMR spectrum. After complete addition of 1 equiv of $\mathrm{Cs}^{+}$the obtained ${ }^{1} \mathrm{H}$ NMR spectrum appears to be the footprint of the one of the complex 3.Cs ${ }^{+}$. This behavior reflects the greater ability of $\mathbf{3}$ to bind $\mathrm{Cs}^{+}$compared to $\mathrm{K}^{+}$, as $\mathrm{Cs}^{+}$is able to replace $\mathrm{K}^{+}$guest. Moreover, if an admixture of cations is added to the chelator $\mathbf{3}$, the obtained ${ }^{1} \mathrm{H}$ NMR corresponds to the one of 3.Cs ${ }^{+}$when $\mathrm{Cs}^{+}$is added alone. Identical trends were observed by UV-visible experiments (see SI Figure S11).

These features constitute a clear proof that the host molecule $\mathbf{3}$ behaves as a specific and selective probe to the cesium cation even if competitive cations are present in the medium.

The intrinsic sensing properties of the novel chelator 3 with respect to $\mathrm{Cs}^{+}$, led us to consider its possible use in a sensor device such as a Chem-FET. Nevertheless, prior to its implementation in a real device it is required to graft it efficiently on a suitable surface. In this context, we have recently demonstrated that SLM (Single Lipid Monolayer $)^{18-21}$ can be used as efficient organic dielectrics in Field Effect Transistors devices. Respectively we have implemented a methodology that ensures us to have SLM with unprecedented mechanical and electrical properties. ${ }^{39,40}$ Based on these relevant facts, we decided to functionalize the chelator $\mathbf{3}$ with an appropriate anchoring group in order to be grafted on an engineered SLM. 


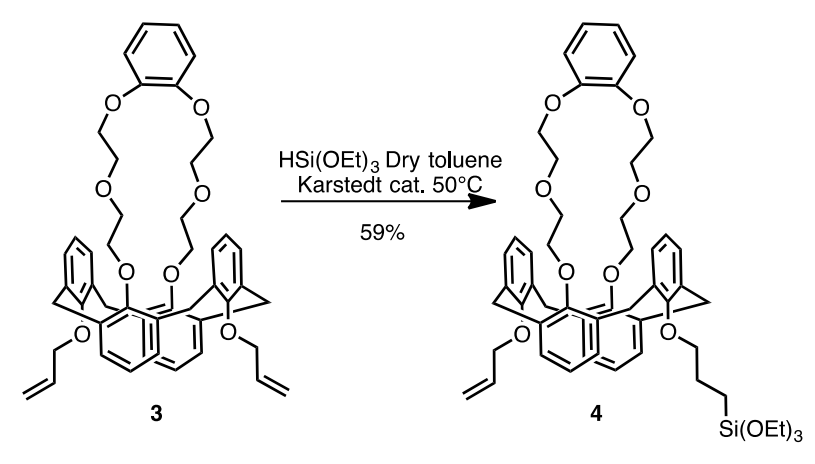

Thus, owing our strategy, the triethoxysilane group was selected and used as anchoring group. From 3, this functional group can be easily introduced on the allyl part of the lower rim in one step using the Karstedt catalyst (Scheme 2). ${ }^{41}$ The target functionalized compound 4 was obtained in $59 \%$ and was used without further purification in the next step. Indeed, compound $\mathbf{4}$ might be also contaminated by the bis-silylated derivative but this will not have any consequence on the grafting (see SI Figure S9).

\section{Scheme 3: Modification of the Single Lipid Monolayer with 4.}

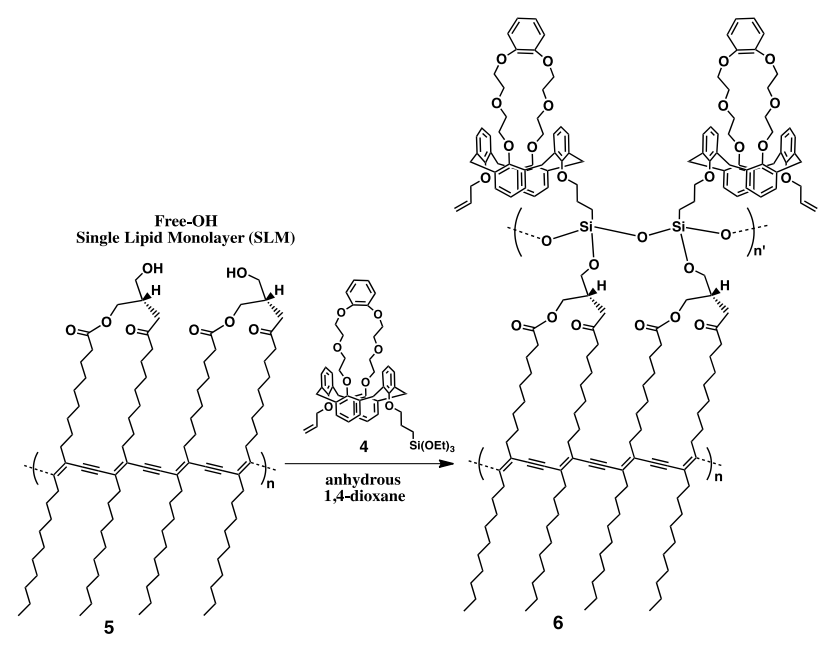

Firstly a sample of a free-OH lipid was assembled on an edge-tailored silicon prism to form a self-assembled monolayer (SAM) and then polymerized within the plane of the monolayer by applying a protocol mastered by our group to form 5. ${ }^{18-21}$ The obtained SLM 5 was successfully characterized in situ; prior to grafting the host compound 4, using a homemade Infrared cell placed in an attenuated total reflectance mode Fourier-transform infrared (ATRFTIR) spectrophotometer (see SI Figure S12). The initiation and propagation of the polymerization in the outer plane was initiated and ensured by the polycondensation of triethoxysilane group with the ester group on the top of the SLM 5 (Scheme 3). It was performed by exposing the supported lipid monolayer to $0.25 \mathrm{mM}$ solution of the substituted chelators 4 in anhydrous 1,4-dioxane. 


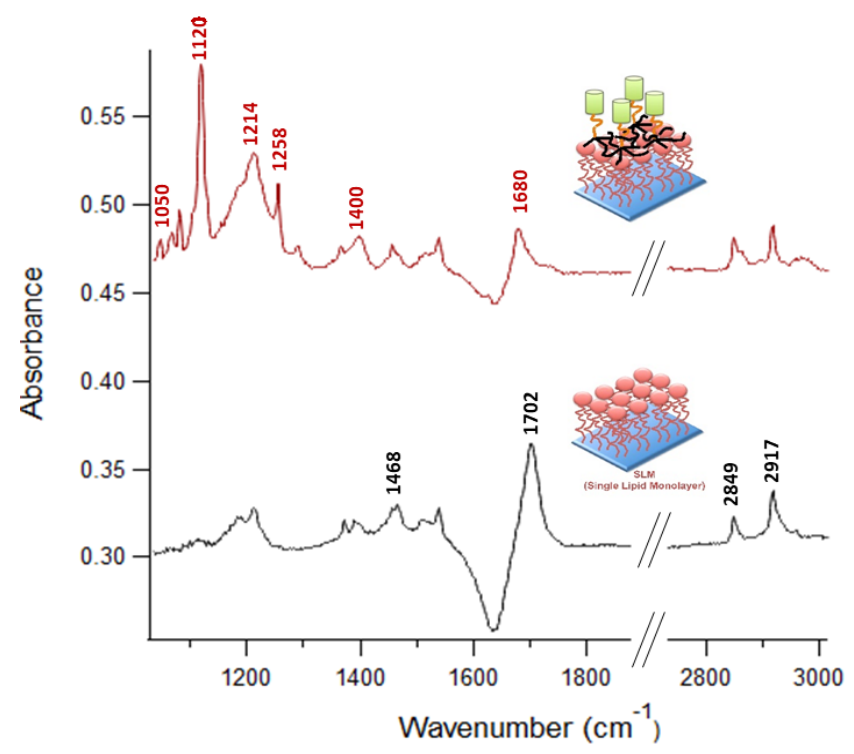

Figure 7: FTIR-ATR spectra of a functionalized lipid monolayer prior to (black plot) and after (red plot) reaction with 4 . The spectra were recorded in water. For both spectra the reference is the silicon surface prior to the adsorption of the lipid monolayer

FTIR spectra confirm the occurrence of the condensation reaction (Figure 7). After $1 \mathrm{~h}$ exposure in the chelator solution and rinsing, a decrease and a shift of the peak assigned to the carbonyl of the ester head groups $\left(v_{\mathrm{C}=\mathrm{O}}\right.$ at $1702 \mathrm{~cm}^{-1}$ ) and the appearance of new bands in the 1000-1300 $\mathrm{cm}^{-1}$ assigned to siloxane and/or calixarene bonding $\left(v_{\mathrm{Si}-\mathrm{O}}, v_{\mathrm{C}-\mathrm{O}}\right)$, indicating the successful anchoring of the host molecule 4 on the surface. In addition the spectra show that the intensity and position of the peaks corresponding to the aliphatic chains of the lipids (sym. $v_{\mathrm{CH} 2}$ at $2849 \mathrm{~cm}^{-}$ ${ }^{1}$ and asym. $v_{\mathrm{CH} 2}$ at $2917 \mathrm{~cm}^{-1}$ ) remain unchanged indicating that the close-packed structure of the lipid monolayer is preserved ${ }^{42}$ All these observations are in favor of a successful anchoring of the host molecule at the surface of the SLM. This unique combination of this novel interface is of great interest to be used as active layer in a ChemFET. Preliminary results based on an electrolyte gated organic field effect transistor (EG-OFET) modified by the modified SLM 6 clearly evidence the capture of $\mathrm{Cs}^{+}$(see SI, Figure S13). Measurements were performed in PBS, i.e. Similar behavior is obtained even in presence of competitive cation like $\mathrm{K}^{+}$or $\mathrm{Na}^{+}$. Thus the tendencies observed from the free chelator 3 in solution are confirmed when the latter is grafted onto the SLM.

\section{CONCLUSION}

We reported herein the synthesis and the characterization of a novel and innovative interface based on the combination of a calix[4] arene tethered with a benzocrown ether and a single lipid monolayer (SLM) that can be used as an effective sensing layer in a Chem-FET. Indeed, the newly appended calix[4]arene possesses remarkable sensitivity and selectivity toward $\mathrm{Cs}^{+}$, over other interfering cations while the SLM presents high mechanical and electrical properties as previously demonstrated. This unique combination of properties makes this innovative and novel interface a system of choice for the foreseen applications. Preliminary results conducted on an EG-OFET have demonstrated the effectiveness of this innovative interface for the specific detection of $\mathrm{Cs}^{+}$. Further work and improvements are now under progress.

\section{ASSOCIATED CONTENT}

\section{Supporting Information}

Figures S2-S13 and experimental part S-1, from the Supporting Information (SI), are available free of charge on the ACS Publications website at http://pubs.acs.org.

\section{AUTHOR INFORMATION}




\section{Corresponding Authors}

*Phone: +33 (0)6 151787 93. E-mail: charrier@inam.univ-mrs.fr (A.M.C.) jean-manuel.raimundo@univ-amu.fr (J.M.R.).

\section{Notes}

The authors declare no competing financial interest.

\section{ACKNOWLEDGMENT}

This research was performed under the framework of the Strategic International Collaborative Research Program (SICORP) and financially supported by the Japan Science and Technology Agency (JST) and l'Agence Nationale de la Recherche (ANR). Project No. ANR-16- JTIC-0003-01. We also thank Michel Giorgi (Spectropôle, Marseille) for the crystal structure determinations. V. K. thanks also the ANR agency for its doctoral financial support.

\section{REFERENCES}

(1) Pasternack, J. B.; Howell, R. W., RadNuc: A Graphical User Interface to Deliver Dose Rate Patterns Encountered in Nuclear Medicine with a 137Cs Irradiator, Nucl. Med. Biol. 2013, 40, 304-311.

(2) Yuan, S.; Chen, D.; Li, D.; Zhong, J.; Xu, X., In Situ Crystallization Synthesis of CsPbBr3 Perovskite Quantum Dot-Embedded Glasses with Improved Stability for Solid-State Lighting and Random Upconverted Lasing, ACS Appl. Mater. Interfaces 2018, 10, 18918-18926.

(3) Burger, A.; Lichtscheidl, I., Stable and Radioactive Cesium: A Review about Distribution in the Environment, Uptake and Translocation in Plants, Plant Reactions and Plants' Potential for Bioremediation, Sci. Total Environ. 2018, 618, 1459-1485.

(4) Murakami, M.; Ohte, N.; Suzuki, T.; Ishii, N.; Igarashi, Y.; Tanoi, K., Biological Proliferation of Cesium-137 through the Detrital Food Chain in a Forest Ecosystem in Japan, Sci. Rep. 2014, 4:3599, 1-5.

(5) Melnikov, P.; Zanoni, L. Z., Clinical Effects of Cesium Intake, Biol. Trace Elem. Res. 2009, 135, 1-9.

(6) Guy, R. H.; Hostynek, J. J.; Hinz, R. S.; Lorence, C. R., Metals and the Skin. Topical Effects and Systemic Absorption, Marcel Dekker, Inc. New York, NY. 1999, 431pp.

(7) Ohno, T.; Muramatsu, Y., Determination of Radioactive Cesium Isotope Ratios by Triple Quadrupole ICPMS and its Application to Rainwater following the Fukushima Daiichi Nuclear Power Plant Accident, J. Anal. Spectrom. 2014, 29, 347-351.

(8) Zheng, J.; Tagami, K.; Bu, W.; Uchida, S.; Watanabe, Y.; Kubota, Y.; Fuma, S.; Ihara, S., 135Cs/137Cs Isotopic Ratio as a New Tracer of Radiocesium Released from the Fukushima Nuclear Accident, Environ. Sci. Technol. 2014, 48, 5433-5438.

(9) Zheng, J.; Bu, W.; Tagami, K.; Shikamori, Y.; Nakano, K.; Uchida, S.; Ishii, N., Determination of 135Cs and 135Cs/137Cs Atomic Ratio in Environmental Samples by Combining Ammonium Molybdophosphate (AMP)selective Cs Adsorption and Ion-Exchange Chromatographic Separation to Triple-Quadrupole Inductively Coupled Plasma-Mass Spectrometry, Anal. Chem. 2014, 86, 7103-7110.

(10) Russell, B.C.; Warwick, P. E.; Croudace, I. W., Calixarene-based Extraction Chromatographic Separation of 135Cs and 137Cs in Environmental and Waste Samples Prior to Sector Field ICP-MS Analysis, Anal. Chem. 2014, $86,11890-11896$.

(11) Ungaro, R.; Casnati, A.; Ugozzoli, F.; Pochini, A.; Dozol, J.-F. ; Hill, C. ; Rouquette, H., 1,2Dialkoxycalix[4]arene crown-6 in 1,3-alternate Conformation: Cesium-Selective Ligands using the Cation-arene Effect, Angew. Chem. Int. Ed. 1994, 33, 1506-1509.

(12) Lamare, V.; Dozol, J.-F.; Fuangswasdi, S.; Arnaud-Neu, F.;Thuéry, P.; Nierlich, M.; Asfari, Z.; Vicens, J., A new Calix[4]arene-bis(crown ether) Derivative Displaying an Improved Caesium over Sodium Selectivity: Molecular Dynamics and Experimental Investigation of Alkali-Metal Ion Complexation J. Chem. Soc. Perkin Trans 2 1999, 271-284. 
(13) Kim, S. K.; Vargas-Zunica, G. I.; Hay, B. P.; Young, N. J.; Delmau, L. H.; Masselin, C.; Lee, C. H.; Kim, J. S.; Lynch, V. M.; Moyer, B. A.; Sessler, J. L., Controlling Cesium Cation Recognition via Cation Metathesis within an Ion Pair Receptor, J. Am. Chem. Soc. 2012, 134, 1782-1792.

(14) Roper, E.D.; Talanov, V. S.; Gorbunova, M. G.; Bartsch, R. A.; Talanova, G. G., Optical Determination of Thallium(I) and Cesium(I) with a Fluorogenic Calix[4]arenebis(crown-6 ether) Containing One Pendent Dansyl Group, Anal. Chem. 2007, 79, 1983-1989.

(15) Yeon, Y.; Leem, S.; Wagen, C.; Lynch, V. M.; Kim, S. K.; Sessler, J. L., 3-(Dicyanomethylidene)indan-1one-Functionalized Calix[4]arene-Calix[4]pyrrole Hybrid: An Ion-Pair Sensor for Cesium Salts, Org. Lett. 2016, $18,4396-4399$.

(16) Kumar, N.; Pham-Xuan, Q.; Depauw, A.; Hemadi, M.; Ha-Duong, N.-T.; Lefevre, J. P.; Ha-Thi, M.-H.; Leray, I., New Sensitive and Selective Calixarene-Based Fluorescent Sensors for the Detection of Cs + in an Organoaqueous Medium, New. J. Chem. 2017, 41, 7162-7170.

(17) Pham-Xuan, Q.; Jonusauskaite, L.; Depauw, A.; Kumar, N.; Lefevre, J. P.; Perrier, A.; Ha-Thi, M. H.; Leray, I., New Water-Soluble Fluorescent Sensors Based on Calix[4]arene biscrown-6 for Selective Detection of Cesium, J. Photochem. Photobiol. A 2018, 364, 355-362.

(18) Nguyen, T. D.; El Zein, R.; Raimundo, J.-M.; Dallaporta, H.; Charrier, A.-M., Label Free Femtomolar Electrical Detection of Fe(iii) Ions with a Pyridinone Modified Lipid Monolayer as the Active Sensing Layer, $J$. Mater. Chem. B 2013, 1, 443-446.

(19) Nguyen, T. D.; Labed, A.; El Zein, R.; Lavandier, S.; Bedu, F.; Ozerov, I.; Dallaporta, H.; Raimundo, J.-M.; Charrier, A.-M., A Field Effect Transistor Biosensor with a $\gamma$-pyrone Derivative Engineered Lipid-Sensing Layer for Ultrasensitive $\mathrm{Fe}^{3+}$ ion Detection with Low pH Interference, Biosens. Bioelectron. 2014, 54, 571-577.

(20) Kenaan, A.; Nguyen, T. D.; Dallaporta, H.; Raimundo, J.-M.; Charrier, A.-M., Subpicomolar Iron Sensing Platform Based on Functional Lipid Monolayer Microarrays, Anal. Chem. 2016, 88, 3804-3809.

(21) Nguy, T. P.; Hayakawa, R.; Kilinc, V.; Petit, M.; Raimundo, J.-M.; Charrier, A.-M.; Wakayama, Y., Stable Operation of Water-Gated Organic Field-Effect Transistor Depending on Channel Flatness, Electrode Metals and Surface Treatment Jpn. J. Appl. Phys. 2019, 58 (SD), SDDH02_1- 5.

(22) For more information, see the website of Spectropôle from Aix Marseille University: https://fr-chimie.univamu.fr/spectropole/.

(23) Dolomanov, O.V.; Bourhis, L. J.; Gildea, R. J.; Howard, J. A. K.; Puschmann, H., OLEX2: A Complete Structure Solution, Refinement and Analysis Program, J. Appl. Crystallogr. 2009, 42, 339-341.

(24) Sheldrick, G., SHELXT - Integrated Space-Group and Crystal-Structure Determination, Acta Crystallogr., Sect. A: Found. Adv. 2015, 71, 3-8.

(25) Yoe, J. H. ; Jones, A. L., Colorimetric Determination of Iron with Disodium-1,2-dihydroxybenzene-3,5disulfonate, Anal. Chem. 1944, 16, 111-115.

(26) Job, P., Spectrochemical Methods of Analysis, Wiley Interscience : New York, 1971, 346pp.

(27) Kim, J. S.; Cho, M. H.; Yu, I. Y.; Pang, J. H.; Kim, E. T.; Suh, I. H.; Oh, M. R.; Ra, D. Y.; Cho, N. S., Calix[4]arene Dibenzocrown Ethers as Cesium Ionophore, Bull. Kor. Chem. Soc. 1997, 18, 677-680.

(28) Kim, J. S.; Yu, I. Y.; Pang, J. H.; Kim, J. K.; Lee, Y.-I.; Lee, K. W.; Oh, W.-Z., New Calix[4]arene Dibenzocrown Ethers for Selective Sensing of Cesium Ion in an Aqueous Environment, Microchem. J. 1998, 58, 225-235.

(29) Ji, H. F.; Dabestani, R.; Brown, G. M.; Hettich, R. L., Synthesis and Sensing Behavior of Cyanoanthracene Modified 1,3-alternate calix[4]benzocrown-6: a New Class of Cs+ Selective Optical Sensors, J. Chem. Soc., Perkin Trans 2 2001, 4, 585-591.

(30) Wright, K.; Melandri, F.; Cannizzo, C.; Wakselman, M.; Mazaleyrat, J. P., New Crown-Carrier C $\alpha, \alpha-$ Disubstituted Glycines Derived from $\alpha$-methyl-(1)-DOPA, Tetrahedron 2002, 58, 5811-5820. 
(31) Deutman, A. B. C.; Smits, J. M. M.; de Gelder, R.; Elemans, J. A. A. W.; Nolte, R. J. M.; Rowan, A. E., Strong Induced-Fit Binding of Viologen and Pyridine Derivatives in Adjustable Porphyrin Cavities, Chem. Eur. J. 2014, 20, 11574-11583.

(32) Weber, E., Neutralliganden mit Tensidstruktur - Synthese, Komplexierung, Ionentransfer, Liebigs Ann. Chem. 1983, 5, 770-801.

(33) Surowiec, M.; Custelcean, R.; Surowiec, K.; Bartsch, R. A., Mono-ionizable Calix[4]arene-benzocrown-6 ligands in 1,3-Alternate Conformations: Synthesis, Structure and Silver(I) Extraction, Tetrahedron 2009, 65, 77777783.

(34) Sessler, J. L.; Kim, S.; Gross, D.; Lee, C.; Kim, J.; Lynch, V., Crown-6-calix[4]arene-Capped Calix[4]pyrrole: An Ion-Pair Receptor for Solvent-Separated CsF Ions, J. Am. Chem. Soc. 2008, 130, 13162-13166.

(35) Hofmeister, F., Zur Lehre yon der Wirkung der Salze, Arch. Exp. Pathol. Pharmakol. 1888, 24, $247-260$.

(36) Lo Nostro, P.; Ninham, B. W., Hofmeister Phenomena: an Update on Ion Specificity in Biology, Chem. Rev. 2012, 112, 2286-2322.

(37) Benesi, H. A.; Hildebrand, J. H. J., A Spectrophotometric Investigation of the Interaction of Iodine with Aromatic Hydrocarbons, J. Am. Chem. Soc. 1949, 71, 2703-2707.

(38) Thordason, P., Determining Association Constants from Titration Experiments in Supramolecular Chemistry, Chem. Soc. Rev. 2011, 40, 1305-1323.

(39) Kenaan, A.; Charrier, A.-M.; Lavandier, S.; Raimundo, J.-M. PCT Int. Appl. 2017, WO 2017064176 A1 20170420.

(40) Kenaan, A.; El Zein, R.; Kilinc, V.; Lamant, S.; Raimundo, J.-M.; Charrier, A.-M., Ultrathin Supported Lipid Monolayer with Unprecedented Mechanical and Dielectric Properties, Adv. Funct. Mater. 2018, 28, 1801024.

(41) Kim, Y.-J.; Jung, H.-S.; Lim, J.; Ryu, S.-J.; Lee, J.-K., Rapid Imaging of Latent Fingerprints Using Biocompatible Fluorescent Silica Nanoparticles, Langmuir 2016, 32, 8077-8083.

(42) Menzel, H.; Mowery, M.D.; Cai, M. and Evans, C.E., Fabrication of Noncovalent and Covalent Internal Scaffolding in Monolayer Assemblies Using Diacetylenes, Macromolecules. 1999, 32, 4343-4350.

\section{GRAPHICAL ABSTRACT}

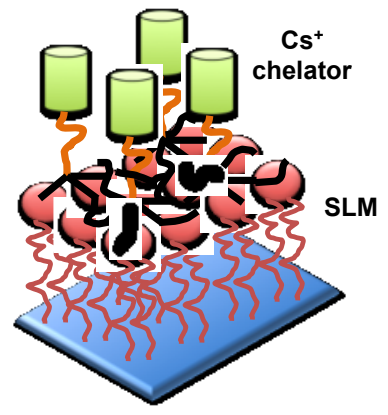

